Электронный научный журнал (Online). ISSN 2303-9922. http://www.vestospu.ru

УДК 372.881.161.1

DOI: $10.32516 / 2303-9922.2019 .31 .22$

\title{
Н. Н. Кузнецова
}

\section{Методические приемы работы над лексическими средствами на занятиях по дисциплине «Филологический анализ текста» в педагогическом вузе}

Статья посвящена актуальной методический проблеме - разработке приемов работы с текстом на занятиях по дисциплине «Филологический анализ текста» и конкретным приемам лексического анализа. Автором выработан и апробирован целый ряд приемов работы над средствами лексического уровня художественного текста, которые, при всем их многообразии, можно объединить в три основные группы: наблюдение над выбором слов, наблюдение над трансформацией значения слова в художественном тексте и наблюдение над способами выражения индивидуальности автора. В ходе филологического анализа они занимают центральное место, поскольку именно эти средства передают основное содержание произведения и свидетельствуют о ценностных ориентирах автора. В статье представлены приемы двух первых групп.

Ключевые слова: художественный текст, филологический анализ текста, студенты педагогического вуза, приемы работы со средствами лексического уровня, выбор слова, трансформация значения слова, нарушение сочетаемости.

Дисциплина «Филологический анализ текста» — важнейшее звено в методической подготовке будущих учителей русского языка и литературы. Она преподается на последнем курсе и является завершающим этапом в овладении студентами профессиональными умениями и навыками, развитии необходимых компетенций. При обучении филологическому анализу текста мы опираемся на знания, полученные в курсах «Современный русский язык», «Стилистика» и «Риторика». В связи с этим филологическому анализу текста придается особое значение, поскольку студенты должны анализировать текст с учетом особенностей всех уровней языка. В процессе анализа они применяют и знания, полученные на методике преподавания русского языка и литературы.

Помимо этого филологический анализ текста непосредственно связан с развитием речевой деятельности учащихся, что является приоритетным в ОГЭ и ЕГЭ. На сегодняшний день инновационная деятельность учителя предполагает значительный акцент именно на анализ текста, при этом требуется не только интерпретация, но прежде всего создание собственного текста (сжатое изложение, пересказ, проблемное сочинение). Поэтому студенты сами должны владеть навыками подобного анализа.

Важно и то, что произведения русской классической литературы являются и образцами высокохудожественного текста с точки зрения формы, и источниками духовности, которые воспитывают студентов и школьников, с точки зрения содержания.

И наконец, «Филологический анализ текста», будучи завершающим этапом в изучении как языковых, так и методических дисциплин, дает студентам представление о «методике методик» - метаязыке, то есть языке обучения современному русскому языку, что на данный момент также является актуальной, малоизученной проблемой. Тем самым повышается уровень аналитической работы студентов вообще и с текстом в частности.

В этой связи несомненный научный интерес представляет выявление наиболее действенных приемов работы со средствами лексического уровня, способствующих обучению студентов филологических факультетов педагогических университетов анализу художественного текста. Овладение этими приемами поможет будущим учителям в их педагогической деятельности в школе.

(C) Кузнецова Н. Н., 2019 
Электронный научный журнал (Online). ISSN 2303-9922. http://www.vestospu.ru

Цель нашего исследования - представить разработки автора в области теории и практики филологического анализа текста по одному из основных направлений работы - с лексическими средствами языка. Хотя форма и содержание художественного текста создаются за счет взаимодействия всех уровней языка, лексические средства в первую очередь приспособлены к актуализации смыслов и выражению всех оттенков семантики и эмоциональной окраски. Поэтому именно они рассматриваются нами подробно и разносторонне.

Для достижения данной цели мы ставили перед собой следующие задачи: 1. Выявить специфику средств лексического уровня в отношении с другими уровнями языковой системы. 2. Представить виды работы с лексическими средствами на занятиях по дисциплине «Филологический анализ текста». 3. Предложить упражнения по каждому виду работ. 4. Дать образцы выполнения этих упражнений. 5. Отметить затруднения, которые могут возникнуть при подаче того или иного материала на лекциях или практических занятиях для преподавателя или (при выполнении упражнения) для студентов, указать приемы, помогающие преодолеть эти трудности.

В работе по филологическому анализу текста мы опираемся на исследования по данной теме лингвистического и методического характера И. В. Арнольд, М. Л. Гаспарова, А. Д. Дейкиной, Ю. М. Лотмана, Н. А. Николиной, Л. А. Новикова, С. В. Пискуновой, Н. Е. Сулименко, И. В. Фоменко и др.

В современной научной методической периодике достаточно много работ посвящено вопросам анализа текста. Причем этот анализ в них называется по-разному (в зависимости от расстановки акцентов): лингвосмысловой у Н. С. Болотновой [9], комплексный у А. В. Блохина [7], речетворческий у А. П. Беловой [6], лингвопоэтический у А. Т. Грязновой [15] и Е. А. Пановой [33], концептуальный у И. Ю. Токаревой [40] и т.д. Хотя у данных авторов не всегда речь идет именно о филологическом анализе текста, тем не менее все эти разработки так или иначе связаны с наблюдением над словом (а значит, над лексическими средствами языка) и поэтому попадают в сферу наших интересов.

А. В. Блохин [7] предлагает в качестве альтернативы творческой части ЕГЭ комплексный лингвистический анализ, где все значимые для понимания произведения единицы языка различных уровней рассматриваются с точки зрения их стилистической функции в тексте. Однако сам автор признает, что временем для этого анализа школьники на государственном аттестационном экзамене не располагают. Тем не менее, если подобная работа при анализе художественного текста будет вестись систематически, возможно, отработанные умения и навыки позволят выполнить творческую часть более успешно и при меньших затратах времени.

Достаточно эффективной, на наш взгляд, может быть система работы с текстом, предложенная О. Н. Левушкиной [24]: урок характеристики художественного текста. По сути это тоже комплексный анализ, но особого рода. Несмотря на то что такой урок проводится в среднем звене (в 6 классе), автор включает в него многие элементы, которые мы рассматриваем при работе с текстом на вузовском уровне со студентами: структурно-содержательная характеристика текста, элементы ассоциативного анализа, лингвистический анализ, эмоциональная характеристика, элементы культурологического анализа и пр. Думается, такой охват вопросов не может не способствовать полноте и адекватности анализа произведения. Однако не менее ценным в данной системе является ее максимальная нацеленность на выработку практических умений, необходимых для сдачи ЕГЭ, поскольку в работе есть такие этапы, как рефлексия, подготовка к сочинению или изложению, разработка алгоритма написания сочинения, черновик сочинения и т.д. Если 
Электронный научный журнал (Online). ISSN 2303-9922. http://www.vestospu.ru

учесть, что у шестиклассников еще достаточно времени для подготовки к экзаменам, то подобные навыки могут стать залогом высоких баллов в будущем.

М. А. Аристова и Ж. Н. Критарова [2] затрагивают важную тему работы с лексическими средствами в полиэтнической школе и отмечают, что изучение культуроведческой лексики улучшает восприятие иноязычного художественного текста.

Метаязыку обучения языку посвящена статья А. Д. Дейкиной и О. Н. Левушкиной [16]. Авторы прослеживают эволюцию приемов анализа текста в школьной методике преподавания русского языка.

Глубокий анализ (поуровневый лингвосмысловой) представлен в статьях Н. С. Болотновой [8; 9]. В центре его - смысл, поскольку «путь к художественному содержанию текста лежит через систему его смыслов» [9, с. 18]. В статьях затрагиваются такие сложные вопросы, как локальная и глобальная интерпретация текста, взаимоотношения формы и содержания, информационно-смысловой и прагматический уровни анализа текста, а также целая система их подуровней, к которым можно отнести все важные для понимания произведения элементы. Подобный подход, несомненно, повысит уровень осознанности, а следовательно, аналитичности работы с художественным текстом.

В целом мы можем отметить, что спектр рассматриваемых вопросов, связанных с лексикой, при работе с художественным текстом в школе очень широк. Исследователи рассматривают текст в контексте культуры (Н. А. Ипполитова [19]), говорят не только об отдельных лексемах, но и о лексико-семантических или смысловых полях (А. Т. Грязнова [15]), ключевых словах и образах (А. Т. Грязнова [15], Е. А. Панова [33], Т. М. Пахнова [35], И. Ю. Токарева [40]), разных видах информации (А. Т. Грязнова [15]) и т.д. Однако все эти аспекты являются составляющими комплексного анализа и не становятся объектами специального рассмотрения в школе. В вузе же мы должны изучить их глубоко и всесторонне.

Интерес к «погружению в текст» объясняется не столько обучающими и воспитательными целями, сколько, по справедливому замечанию Н. С. Болотновой, «антропоцентризмом гуманитарного знания» вообще. «Человек не может жить не общаясь, а общение происходит на основе текстовой деятельности [9, с. 16].

Однако при всем многообразии современных публикаций, посвященных анализу текста, основная их часть представляет собой разработки уроков в школе по конкретным произведениям. Конечно, студенты, окончив вуз, могут воспользоваться уже готовыми схемами и приемами. Но основная проблема заключается в том, чтобы дать такие теоретические сведения и выработать такие практические навыки, которые позволят им самим творчески подходить к этому процессу и быть готовыми проанализировать любое произведение.

Дисциплина «Филологический анализ текста» преподается в Оренбургском государственном педагогическом университете на всех профилях направления 44.03.05 Педагогическое образование (с двумя профилями подготовки): «Русский язык и Литература», «Русский язык и Начальное образование», «Русский язык и История». Учебным планом предусмотрены лекции, практические занятия и лабораторные работы (на разных профилях разное, но достаточное количество часов).

На занятиях по филологическому анализу текста важное место занимает кропотливая, трудоемкая работа со средствами различных уровней языка, создающими выразительность текста, а значит, по закону выдвижения, призванными в первую очередь выражать основные смыслы произведения, опора на которые помогает понять ключевые образы художественного текста, направление мысли автора и его ценностные ориентиры. 
Электронный научный журнал (Online). ISSN 2303-9922. http://www.vestospu.ru

Это средства фонетического уровня (особенно значимые для поэтического текста), в меньшей степени - средства морфологического, морфемного, словообразовательного и других уровней (которые могут брать на себя основную смысловую нагрузку в отдельных произведениях) и, конечно, лексические и синтаксические. Последние, несомненно, лидируют среди средств всех уровней языка при создании выразительности и передаче основного идейного содержания. Это связано с тем, что лексические средства, обладающие значением, в первую очередь способны актуализировать смыслы. Кроме того, многие слова стилистически маркированы, а следовательно, могут выражать и нюансы отношения говорящего к предмету речи. Однако слова выражают смысловые и эмоциональные оттенки не изолированно, а в тех или иных синтаксических конструкциях: предложении, сложном синтаксическом целом и тексте. Поэтому средства синтаксического уровня столь же значимы.

Вследствие этого вначале необходимо дать студентам теоретические знания о средствах различных уровней языка (что и происходит на занятиях по «Современному русскому языку»). А в рамках дисциплины «Филологический анализ текста» мы уже наблюдаем за этими средствами в тексте. Тщательный анализ языковых единиц различных уровней позволит, с одной стороны, воспринять все многообразие средств арсенала авто$\mathrm{pa}$, a с другой — глубже, а значит, более адекватно постичь художественное произведение в целом.

В первую очередь (и очень детально) мы изучаем средства лексического уровня: главные средства создания образности - тропы; собственно словарный состав языка, все богатство которого позволяет автору максимально точно выразить свою мысль и отношение к предмету речи; системные связи слова, среди них особенно выделяются и наиболее активно задействованы синонимия, антонимия и паронимия. В том или ином произведении повышенным экспрессивным потенциалом могут обладать слова, рассмотренные ранее в курсе «Лексикологии» в составе различных классификаций:

- с точки зрения сферы употребления - диалектизмы, жаргонизмы, профессионализмы;

- с точки зрения происхождения - заимствованная лексика;

- с точки зрения экспрессивно-стилистических свойств - стилистически маркированная - книжная и разговорная;

- с точки зрения активного и пассивного запаса - устаревшая и новая.

Богатейшим стилистическим потенциалом обладают и устойчивые сочетания слов фразеологизмы.

В данной статье мы представим одно из направлений работы с текстом: с лексическими средствами всех названных типов. Однако наша задача - не рассмотрение средств лексического уровня как таковых, необходимо выделить наиболее эффективные виды работы с ними на уроках русского языка. Мы объединили упражнения в три группы:

1) наблюдение над выбором слов;

2) наблюдение над трансформацией значения слова в художественном тексте;

3) наблюдение над способами выражения индивидуальности автора.

Слова составляют основу любого художественного текста. Именно их выбор характеризует манеру того или иного автора, позволяет отличить его произведения от произведений других авторов.

Tрансформация значения слова - конститутивное условие существования художественного произведения. Трансформации подвержены лексемы, участвующие в создании тропов и фигур, т.е. слова в переносном значении. В целях создания нового, свежего, необычного образа автор помещает слово в необычный для него контекст, в результате возникают новые или дополнительные смыслы, узуально за словом не закрепленные. 
Электронный научный журнал (Online). ISSN 2303-9922. http://www.vestospu.ru

Анализируя авторский стиль того или иного автора, можно выделить ряд языковых особенностей. Такой стиль формируют три составляющие. Это прежде всего неповторимый взгляд автора на мир, складывающийся либо с опорой на богатейшие традиции русской литературы, либо с отталкиванием от них. Русская литература, пережившая Золотой и Серебряный век в своем развитии, насчитывает огромное множество высокохудожественных образцов интерпретации литературных тем, основных мотивов и отдельных образов - так называемых традиционных поэтических денотатов. Существуют многотомные словари, в которых собраны многочисленные трактовки одного и того же образа у разных поэтов и писателей $[13 ; 25]$. И в связи с этим создать нечто новое, яркое, привлекающее читателя своей необычностью, все сложнее. Поэтому в XX-XXI веках появился целый ряд авторов, чья творческая манера построена на отталкивании от литературных традиций (например, М. Цветаева, Б. Пастернак, И. Бродский, А. Вознесенский и др.). Именно это и позволило им создавать неожиданные, экспрессивные, подчеркнуто индивидуальные образы.

Использование различных видов работ по этим трем направлениям, по нашему мнению, предопределяет успех филологического анализа текста в целом. Однако в рамках данной статьи мы рассмотрим только первые две группы приемов работы с лексическими средствами: 1) связанные с особенностями выбора слов и 2) с трансформацией значения слова. Особенности выбора слов (или особенности лексического состава произведения) в большей или меньшей степени отмечаются при всех названных выше видах анализа, однако вопросы типологии упражнений при изучении этой темы в вузе ранее не освещались. Еще реже в исследованиях подобного рода отражена проблематика трансформации значения слова. В этом плане выделяется статья А. П. Беловой, которая связывает возникновение новых смыслов у слова с речетворческим анализом [6, с. 26]. При вузовском филологическом анализе текста мы рассматриваем механизмы трансформации значения слова как основную особенность языка художественного произведения, без которого оно немыслимо, поэтому приемам работы по различным аспектам данной темы уделяется самое пристальное внимание. Это и вызвало необходимость настоящего исследования.

Существует еще один важный аспект, касающийся работы со средствами лексического уровня. М. Л. Гаспаров отмечал, что в XIX веке филологи при анализе художественного текста отталкивались от биографии автора, от эпохи, в которой он жил. В XX веке акцент в исследованиях сместился на поиск подтекста и интертекста в тексте. Однако «начинать (курсив мой. - H. К.) нужно со взгляда на текст и только на текст - и лишь потом, по мере необходимости для понимания, расширять свое поле зрения» [13, с. 9]. По нашему мнению, работа с лексическими средствами при филологическом анализе текста и представляет собой именно начальный этап.

Всегда необходимо помнить, что основные смыслы и выразительность текста создаются гармоничной работой всех языковых уровней. На уроках русского языка, кроме того, важно показать, какие виды работ можно использовать при анализе различных языковых единиц. При этом мы не утверждаем, что тот или иной смысл или эмоция в художественном тексте может передаваться только какой-то одной единицей языка вне взаимосвязи с другими. Однако опираться на определенное языковое средство, отталкиваться от него для того чтобы выявить общеее содержание текста, его отрывка или отдельного образа на уроках русского языка, представляется целесообразным. И лексические средства, обладающие полностью сформированной семантикой, выражающие ее эксплицитно (и в то же время способные развивать семантику имплицитную), дают нам возможность использовать разнообразные виды работ с текстом и на начальном этапе, и на последующих при постижении общего смысла произведения. 
Электронный научный журнал (Online). ISSN 2303-9922. http://www.vestospu.ru

\section{1. НАБЛЮДЕНИЕ НАД ВЫБОРОМ СЛОВ}

Одни из названных нами видов работ мы рассмотрим более подробно; другие - в силу значительного объема или, наоборот, очевидности — только кратко охарактеризуем или назовем.

1.1. Работа с незнакомыми словами. Это первичный и самый простой вид работы, но тем не менее необходимый. Прежде чем обратиться к анализу текста, учащиеся должны понимать в нем все слова. Можно заранее дать задание подготовить сообщение о лексическом значении того или иного слова. Или (с аналогичной целью) обратиться к словарям или другим источникам. Можно выяснить значение слова и непосредственно на занятии — в Интернете.

1.2. Работа с окказионализмами. Аналогичный вид работы, который должен проводиться на первых этапах анализа текста. И на практических занятиях, и на уроках русского языка в школе необходимо уяснить значение индивидуально-авторского слова, опираясь на контекст и образную составляющую. Кроме того, нужно проанализировать, имеет ли окказионализм художественную ценность, насколько оправданно создание нового слова.

1.3. Наблюдение над выбором слов. Достаточно простой вид работы, когда мы пытаемся выяснить, слова какой семантики преобладают в произведении. Помимо этого в отдельных произведениях может доминировать та или иная часть речи. Имена существительные и имена прилагательные дают статичность описания, в то время как глаголы динамичность. М. Л. Гаспаров, предложивший свою методику анализа художественного текста, подчеркивал, что каждое существительное создает образ - «чувственно вообразимый предмет или лицо»; каждый глагол «отражает мотив», а «последовательность взаимосвязанных мотивов образует сюжет» [13, с. 19]. «Мотивы» и «сюжеты», в терминологии Гаспарова, - это наиболее важная, новая, меняющаяся от ситуации к ситуации, т.е., по сути, предикативная информация. Наряду с глаголами ее выражают и прилагательные, которые, как известно, также обладают способностью к актуализации подобной семантики, а она, в свою очередь, всегда имеет отношение к общему, идейному содержанию художественного текста или концептуальной информации. Ее анализ касается уже не лингвистических, а литературоведческих аспектов. Следовательно, при опоре на такой простой элемент формы, как частеречная принадлежность слов произведения, нам будут более понятны его главные смыслы (а их проанализировать гораздо сложнее).

Для большинства художественных текстов характерно активное употребление изобразительных средств, в частности тропов, т.е. лексем в переносном значении. В связи с этим обращают на себя внимание тексты, в которых они имеют небольшой удельный вес, например произведения А. С. Пушкина. Несмотря на почти полный отказ от тропов, их отличает яркая образность и, как следствие, выразительность.

1.4. Составление словаря произведения. Лексический состав текста, т.е. выбор и отбор средств, частотность тех или иных единиц, а также их расположение - соположение (т.е. повтор, дублирование смыслов) или контрастность - может дать нам представление о мыслях и чувствах автора, его ценностных установках, предпочтениях, интересах, жизненном опыте и т.д. Помимо индивидуального стиля автора, отбор языковых средств в художественном тексте может быть обусловлен: а) жанром, б) литературным направлением, в) тематикой.

На отбор и выбор лексических средств влияет и то, какое именно содержание хочет передать автор - денотативное, эмотивное или концептуальное, а также как он хочет его передать - эксплицитно или имплицитно. 
Электронный научный журнал (Online). ISSN 2303-9922. http://www.vestospu.ru

Чтобы проследить, каковы особенности стиля автора, и выявить важные для понимания произведения смыслы, можно использовать такой вид работы, как «составление словаря текста». По словам Ю. М. Лотмана, «составив словарь того или иного стихотворения, мы получаем - пусть грубые и приблизительные - контуры того, что составляет мир с точки зрения этого поэта» [25, с. 92].

Рекомендуя студентам (и школьникам) составить словарь того или иного произведения, мы можем опираться либо на семантический критерий и дать задание выписать слова определенной тематики, либо на частеречный (предварительно ознакомившись и составив представление о том, какая часть речи превалирует в тексте). Однако если использовать частеречный критерий, то необходимо помнить, что в этом случае мы обязательно будем говорить о взаимодействии средств морфологического и лексического уровней, поскольку тогда категориальное значение предметности накладывается на семантику слова и его стилистическую окраску.

Проиллюстрируем, как можно проанализировать текст при помощи данного вида работы, на примере стихотворения Г. Иванова «Я не любим никем! Пустая осень!» [17, c. 63] (дается задание выписать все существительные):

Я не любим никем! Пустая осень!

Нагие ветки средь лимонной мглы;

А за киотом дряхлые колосья

Висят, пропылены и тяжелы.

Я ненавижу полумглу сырую

Осенних чувств и бред гоню, как сон.

Я щеточкою ногти полирую

И слушаю старинный полифон.

Фальшивит нежно музыка глухая

О счастии несбыточных людей

У озера, где, вод не колыхая,

Скользят стада бездушных лебедей.

Студенты выписывают: осень, ветки, мәла, киот, колосья, полумгла, чувства, бред, сон, щеточка, ногти, полифон, музыка, счастье, люди, озеро, воды, стада, лебеди. Мы пытаемся определить, в какой мере направленность семантики имен существительных дает представление о смысловом и эмоциональном содержании произведения.

По словам В. А. Лукина, филологический анализ носит «циклический» характер, который состоит в постоянных переходах «от содержания к форме и обратно». Л. Ю. Максимов использует термин «челночный» (цит. по: [18, с. 6]). Цикличность анализа поэтического произведения проявляется в том, что мы должны начать с аспектов, касающихся содержания (тема произведения), затем обратиться к форме (определению жанра стихотворения). При комментировании ключевых образов мы одновременно затрагиваем вопросы и формы (какими языковыми средствами создаются эти образы) и содержания (выявляя смыслы, которые они выражают, и эмоции, которые передают). И в заключение необходимо вновь вернуться к содержанию, сделав общий вывод об особенностях трактовки темы, об идее произведения и особенностях мировидения автора.

Ознакомившись с текстом произведения, студенты сообщают, что это философская лирика. Они должны ответить на вопрос: что говорит о направлении мысли лирического героя и его эмоциональном состоянии семантика существительных? Следует отметить, что когда мы выписываем из лирического произведения только имена существительные, то, по сути, знакомимся со всеми его образами (напомним слова М. Л. Гаспарова: «каждое существительное создает образ» [13, с. 19]). При этом очень четко становятся видны при- 
Электронный научный журнал (Online). ISSN 2303-9922. http://www.vestospu.ru

сутствующие в тексте оппозиции. А в поэтическом тексте они, как правило, имеют место, создавая эмоционально напряженную атмосферу. Среди существительных, которые мы выписали, заметен значительный тематический разброс: здесь и поэтические слова (мгла, бред, сон), и слова, называющие элементы пейзажа (осень, ветки, воды), и чисто бытовая лексика (щеточка, ногти, полифон) и т.д. Такая разноаспектность семантики существительных дает возможность говорить об отсутствии противопоставлений, а следовательно, характер образов произведения создает достаточно ровный эмоциональный фон.

Эмоционально-экспрессивная окраска существительных также не указывает на какиелибо ярко выраженные эмоции. Можно отметить только сочетание стада лебедей, котоpoe, в нарушение поэтической традиции, диктующей положительную, высокую трактовку поэтического денотата лебеди, представляет его в ироничном ключе.

Таким образом, в тексте отсутствуют элементы, создающие напряженную эмоциональную тональность. Стихотворение посвящено осени. Угасание красок, замирание жизни в природе могут вызвать в человеке и полное отчаяние, и тоску. Однако у лирического героя смена времен года не способствует возникновению каких-то мрачных мыслей (что часто встречается в произведениях данной тематики). Он спокойно (временами с иронией) наблюдает за всеми проявлениями жизни. Мы видим философскую отстраненность, когда мудрость помогает принять все происходящее.

Таково содержание произведения. Конечно, выводы о его теме и идее мы делаем, учитывая взаимосвязь всех языковых единиц в тексте, тем не менее работа с опорой на имена существительные помогает выявить основные смыслы и эмоциональную составляющую текста.

Безусловно, такой вид работы требует от учителя предварительной подготовки, цель которой - определить, какая именно часть речи (или семантическая группа) превалирует в выражении главных смыслов произведения.

1.5. Работа с ключевыми словами. Несомненно, это один из наиболее важных видов работы, поскольку ключевые слова, или, по терминологии И. В. Арнольд, «тематическая сетка текста» [3, с. 4], в полной мере выражают не только основные смыслы произведения, но могут указывать на доминанты творчества какого-либо автора, его ценностные ориентиры, специфику его картины мира.

Над ключевыми словами мы можем работать и при наблюдении над выбором слов, и при анализе трансформации значения слов в художественном тексте, и при выявлении признаков индивидуализации стиля.

Разноаспектность, в свою очередь, связана с сущностными характеристиками ключевых слов. По общепринятому мнению, это: 1) частотность, повторяемость в тексте (текстах); 2) постоянное изменение, трансформация семантики (в том числе и образование новых, окказиональных смыслов) [4, с. 50]. В то же время характер ключевых лексем, преобладающих в творчестве того или иного автора (или на определенном этапе), глубоко индивидуален, составляет значительный фрагмент его картины мира. Так, например, мы обращаем внимание студентов на лексему «ржавый» в творчестве А. Блока или на лексему «музыка» в произведениях Г. Иванова.

И. Ю. Токарева предлагает анализировать ключевые слова по шагам [40]. Так, первым шагом, который может помочь в понимании значения ключевого слова, является анализ его этимологии. Такой анализ возможен при работе с поэтическими текстами, в которых новое, трансформированное, значение слова опирается на его внутреннюю форму - первичное значение исходного корня. Второй шаг — изучение семантической структуры слова. Значения, которые закреплены за словом узуально, могут предопреде- 
Электронный научный журнал (Online). ISSN 2303-9922. http://www.vestospu.ru

лять направление трансформации значения лексемы в художественном тексте, позволять развиваться определенной семантике. Третий шаг - анализ синонимических и антонимических отношений слова в тексте, которые позволяют сформулировать, скорректировать новое значение лексемы. И наконец, четвертый шаг - подбор и объяснение пословиц, поговорок, афоризмов, текстов других авторов с ключевым словом. На наш взгляд, этот последний шаг очень важен при филологическом анализе текста, причем не только в отношении ключевых слов, но и любого образа. Подбор устойчивых словосочетаний и выражений, поэтических текстов с ключевым словом позволяет студентам развивать ассоциативное мышление, необходимое при анализе художественного текста. Возникающие в нашем сознании представления, связанные с тем или иным образом, с устойчивыми выражениями разного рода, позволяют носителям языка максимально точно определить новую семантику лексем, создать в своем воображении яркий, наглядный образ и тем самым глубже постичь смысл произведения в целом. Далеко не в каждом случае рассмотрение семантики ключевого слова требует всех четырех шагов. Не всегда в контексте могут быть синонимы и антонимы ключевого слова, и еще реже авторы развивают семантику слова путем работы над внутренней формой. Однако мы всегда можем опираться на анализ семантической структуры и ассоциации с ключевым словом.

Ключевые слова могут функционировать либо в одном тексте, либо в разных произведениях на протяжении всего творчества автора, либо на каком-то его этапе. Выбор и характер трансформации ключевых лексем может быть также результатом влияния каких-либо факторов на жизнь и творчество того или иного писателя. Так, например, исследователи творчества И. А. Бунина отмечают сильное влияние русской волшебной сказки, которое проявилось в целом ряде его лирических произведений. В частности, поэту было свойственно изображать мир живых существ с особой проникновенностью, как бы отождествляясь с ними, и в то же время подчеркивать независимость природы от человека, персонифицировать ее (цит. по: [23, с. 309]).

Студентам предлагается найти ключевое слово и проанализировать характер его использования на примере нескольких стихотворений И. А. Бунина [12], где в качестве ключевого слова выступает лексема волчий (в раздаточном материале для студентов лексема не выделена).

Это волчьи глаза или звезды — в стволах на краю перелеска?

Полночь, поздняя осень, мороз.

Голый дуб надо мной весь трепещет от звездного блеска,

Под ногою сухое хрустит серебро.

Затвердели, как камень, тропинки, за лето набитые.

Ты одна, ты одна, страшной сказки осенней Коза!

Расцветают, горят на железном морозе несытые

Волчьи, божьи глаза.

(Сказка о Козе) [12, с. 81]

Еще блестит оконное стекло,

Но волчьей мглой поля заволокло,

На севере огни полночных звезд

Горят из мглы, как из пушистых гнезд.

(«Ночь зимняя мутна и холодна...») [12, с. 67]

Ночь - долгая, хмурая, волчья,

Кругом все снега и снега, 
Электронный научный журнал (Online). ISSN 2303-9922. http://www.vestospu.ru

А в доме лишь мы да иконы

Да жуткая близость врага.

(«Мы сели у печки в прихожей...») [12, с. 140]

Студенты находят ключевое слово волчий (на что указывает его частотность) и определяют его семантику в каждом случае: помимо основного значения принадлежности в приведенных контекстах лексема также актуализирует следующие смыслы: 'рок, судьба', 'зло вообще', 'страшная, неведомая опасность'. Следовательно, слово волчий обладает и вторым конститутивным свойством ключевых слов - трансформирует свою семантику.

Работа с ключевыми словами позволяет сделать и более глобальные выводы об особенностях творчества того или иного поэта, и более конкретные, касающиеся смысловой, образной и эмоциональной составляющих произведения. У И. А. Бунина слово «волчий» как следствие увлечения русским фольклором стало маркером определенного этапа его творчества. А в целом явилось фактором, способствующим дальнейшему развитию неповторимого стиля поэта.

Как видим, работа с ключевыми словами - это тоже своего рода семантизация, только более сложного порядка. И к четырем шагам, предложенным И. Ю. Токаревой, можно добавить пятый - изложение сведений о причинах частотности слова в творчестве того или иного автора. Данный шаг, по нашему мнению, более актуален для вуза, поскольку студенты как будущие учителя должны обладать более глубокими знаниями о причинно-следственной обусловленности подобных фактов.

1.6. Работа с разными редакциями текста. Достаточно продуктивный вид работы, который всегда вызывает интерес у студентов и школьников. Его, конечно, следует проводить с высокохудожественными текстами настоящих мастеров слова. Например, с произведениями А. С. Пушкина, А. Ахматовой, которые, как известно, тщательно работали над выбором слова.

На примере стихотворения «Песнь о вещем Олеге» студентам дается задание: определить, как влияет замена слов в окончательной редакции на смысл, образную систему и эмоциональный фон произведения, насколько точно она соответствует теме, идее, образной структуре и эмоциональному фону произведения по сравнению с ранними редакциями.

Рассматриваем первую замену. Было: «С дружиной своей в цареградской броне Князь по полю едет на смирном коне». В конечном варианте: «Князь по полю едет на верном коне». Обратившись к произведению в целом, студенты после обсуждения приходят к выводу, что такое качество, как смирный, в данном случае никак не характеризовало бы ни коня, ни ситуацию, никак не было бы связано с развязкой. Другими словами, было бы малоинформативным. Эпитет же верный отвечает ситуации: конь, наверное, ни разу не подвел своего хозяина, и при этом Олег, прислушавшись к предсказанию, не пожалел его, своего верного товарища.

Переходим ко второй замене. Было: «Из темного леса навстречу ему Идет престарелый кудесник». Стало: «Идет вдохновенный кудесник». Эпитет престарельй вызывает ассоциации о немощности; кудесник же в стихотворении немощным не был, напротив, дальнейшие события показали силу его дара.

Третья замена. Было: «И к гордому старцу подъехал Олег». Стало: «И к мудрому старцу подъехал Олег». Студенты отмечают, что гордость никак не связана с сюжетом стихотворения. Кроме того, кудесник не мог гордиться перед князем. Мудрость же его была доказана.

Четвертая замена. Было: «Пирует с дружиною вещий Олег При звоне веселом стакана. И кудри их белы, как утренний снег Над ветхой главою кургана». Стало: «...Над 
Электронный научный журнал (Online). ISSN 2303-9922. http://www.vestospu.ru

славной главою кургана». Студенты отвечают, что ветхость говорит о чем-то забытом и не заслуживающим славы, в противоположность эпитету славный. А славу вещий Олег, несомненно, заслужил.

Подобная работа, когда мы видим, как автор отказывается от первоначальных вариантов и выбирает слово, наиболее соответствующее содержанию произведения, его образной структуре и эмоциональному фону, способствует тому, что мысли и чувства, которые хотел донести до читателя поэт или писатель, становятся для студентов более ясными и зримыми, помогают глубже проникнуть в суть текста.

1.7. Сравнительный анализ. Для данного вида работы берутся произведения разных авторов на одну и ту же тему. Такая работа требует наиболее тщательной и длительной подготовки, поскольку прежде чем предложить подобный вид анализа, необходимо составить достаточно подробный план (вопросник), по которому студенты (а затем и школьники) будут сопоставлять произведения. Вопросы должны касаться как содержания произведения, так и формы (языковых единиц различных уровней, передающих содержательные моменты). И в то же время этот вид работы является наиболее наглядным: при сопоставлении мы более явственно можем увидеть особенности языка того или иного автора, понять его взгляд на мир. Например, Н. А. Николина в пособии предлагает рассмотреть такие произведения, как «Выстрел» А. С. Пушкина и «Олеся» А. И. Куприна [28]. Они объединены тем, что их содержанием является жизнь в отдаленном селении, вынужденное бездействие и скука, а повествование ведется от первого лица. При этом имеется целый ряд различий: сословия рассказчиков, их характеры и т.д.

\section{2. ТРАНСФОРМАЦИЯ ЗНАЧЕНИЙ СЛОВ В ХУДОЖЕСТВЕННОМ ТЕКСТЕ}

Возникновение новых смыслов слов - процесс, в первую очередь характеризующий язык художественной литературы (и отчасти публицистики) и делающий его таким выразительным и эмоциональным. Образование тропов и фигур, которые должны активно воздействовать на воображение читателя и вызывать разнообразные ассоциации, не может не сопровождаться развитием совершенно новой, иногда неожиданной, семантики у слова.

2.1. Работа с многозначными словами и омонимами. И в курсе «Современный русский литературный язык», и на занятиях по дисциплине «Филологический анализ текста» мы акцентируем внимание студентов на том, что по сравнению с такими системными связями, как синонимия и антонимия, у многозначности и омонимии меньше возможностей в плане создания выразительности. Наибольший экспрессивный эффект при использовании омонимов и многозначных слов возникает при языковой игре. В подобных случаях в тексте может быть одно или два слова, но обязательно задействуются два значения, от столкновения которых и возникает юмористический эффект. Например: «Иногда мы подводим итоги, иногда они нас»; «Она была завита, как овца, и также развита» (известные юмористические фразы, имеющие широкое хождение в Интернете, принадлежащие А. Кнышеву и Э. Кроткому).

В поэзии случаи создания языковой игры при помощи омонимов и многозначных слов встречаются значительно реже. Тем не менее, если в тексте данные средства имеют место, их необходимо прокомментировать.

Чтобы уяснить механизм работы данных средств в тексте, а также специфику работы с ними на уроке, студентам дается задание: определить значения, в которых выступает многозначное слово (или омоним) в приведенных фразах. В первом примере слово подводим одновременно актуализирует значения: 'делать вывод' (в составе фразеологизма «подводить итоги») и 'разочаровать'. Во втором примере слово развита также реализует одновременно два значения: в силу соседства со словом завита читательские ассоци- 
Электронный научный журнал (Online). ISSN 2303-9922. http://www.vestospu.ru

ации по инерции идут в направлении 'кудри', в то время как речь уже идет о развитии (скорее всего, умственном).

Обращаем внимание на то, что не всегда второе из двух значений, которые актуализируются одновременно в подобных контекстах, является узуальным, т.е. зафиксировано в словаре. Очень часто наблюдается трансформация значения, слово приобретает новый смысл. И именно его формулировка представляет некоторую трудность для студентов и учащихся. Поэтому при использовании данного вида работы в школе студенту (учителю) необходимо определить его заранее.

2.2. Работа со словами в переносном значении. Начиная этот вид работы, напоминаем студентам, что все новые смыслы, возникшие в результате трансформации значения слова в художественном тексте, являются переносными. Подобное упражнение является достаточно простым в этом блоке, чисто лингвистическим, и поэтому его можно использовать на начальных этапах анализа и проводить на небольших отрывках текста (например, поэтического), выбрав наиболее интересные, ключевые образы, а не все слова в переносном значении.

Задание: найти слова в переносном значении, прокомментировать их, определить тип переноса (и тропа) в стихотворении В. Набокова [27, с. 76]: «Как жадно, затая дыханье, склоня колена и плеча, напьюсь я хладного сверканья из придорожного ключа». В данном контексте выделяем слова в переносном значении колена и плеча (тип переноса метонимия). При изучении лексикологии на первом курсе мы в основном рассматривали метонимию, выраженную именами существительными. В данном случае, как правило, имеет место соотношение «часть — целое» или, наоборот, «целое - часть». Студенты находят в тексте слова, переносное значение которых основывается по одной из этих моделей: слова колена и плеча называют часть, а подразумевается целое - человек.

В современной лингвистике рассматривается и метонимия, выраженная именем прилагательным (дискурсивная метонимия) или глаголом. Как показывает опыт работы, такие случаи вызывают затруднения у студентов. Поэтому для разграничения метафорического и метонимического переноса, а также для уяснения специфики последнего предлагаем использовать следующие критерии. Метафору (поскольку она основана на сходстве) можно трансформировать в сравнение. Метонимия же (основанная на смежности), как правило, всегда представляет собой деформированную, сокращенную конструкцию, которую можно восстановить, и не допускает трансформации в сравнение. Опираясь на предложенные приемы, студенты находят в данном отрывке еще одно слово в переносном значении: лексема сверканья представляет собой сложное тропеическое образование, поскольку совмещает в себе оба типа переносных значений. Это метафора (так как имеет место сравнение воды с чем-то сверкающим, например с драгоценными камнями) и метонимия (так как имеет место сокращение конструкции: напьюсь хладного сверканья - напьюсь сверкающей воды).

Или: «И снова, как в милые годы тоски, чистоты и чудес, глядится в безвольные воды румяный редеющий лес» [27, с. 92]. В предложенном тексте находим слова с метафорическим переносным значением: глядится (отражается), безвольные (гладкие, спокойные), румяный (красного оттенка). Все их можно трансформировать в сравнение (как будто глядится, словно безвольные, как румяный). Словом с метонимическим переносным значением является лексема милье (нельзя переделать в сравнение и можно восстановить усеченную конструкцию: милые годы - годы, которые милы).

Студенты отмечают, что предложенные приемы значительно облегчают определение типа переносного значения. 
Электронный научный журнал (Online). ISSN 2303-9922. http://www.vestospu.ru

2.3. Нарушение сочетаемости. Нахождение случаев нарушения сочетаемости как вид работы также может играть роль вспомогательного упражнения, поскольку не требует глубокого анализа содержания текста (что важно при выполнении других упражнений), а побуждает обращать внимание прежде всего на языковую сторону тропа, поэтому может использоваться на начальных этапах анализа произведения.

В словосочетании, где присутствует слово в переносном значении, всегда наблюдается нарушение сочетаемости. Например, у В. Набокова судорога света (судорога может быть только у человека); бессвязные узоры сумрака (бессвязной может быть только речь человека) и проч. Значение слова и его сочетаемость - это два теснейшим образом связанных процесса. Семантика влияет на употребление слова в том или ином контексте; контекст влияет на изменение семантики слова. Без нарушения сочетаемости образования переносного значения не происходит.

Выявляем случаи нарушения сочетаемости в следующих текстах. «Сосед-петух над клушей мельтешил. А наш петух тоску свою глушил, такое видя, в сильных кукареках» $[11$, т. 2, с. 17]. В ходе обсуждения приходим к следующим выводам. В данном случае слово кукареки является окказионализмом: имя существительное образуется от междометия - неизменяемого слова, валентность которого отличается от валентности имени существительного. Нарушение сочетаемости происходит в связи с приобретением междометием грамматических свойств имени существительного (формы числа и падежа) и, как следствие, способности сочетаться с именем прилагательным сильные. Семантические связи также нарушаются. Окказионализм кукареки мог бы сочетаться с лексемами громкие, истошные, оглушительные, что можно увидеть, если заменить индивидуально-авторское слово подходящим к ситуации словом крики (ср.: громкие, истошные, оглушительные крики, но не сильнье крики).

Или: «Я в хоровод теней, топтавших нежный луг, с певучим именем вмешался, но все растаяло, и только слабый звук в туманной памяти остался» [26, с. 212]. Студенты отмечают, что в данном случае нарушение сочетаемости прежде всего обусловлено контрастностью семантики слов: тени по причине своей легкости, эфемерности топтать не могут.

Это упражнение (выявление случаев нарушения сочетаемости слов) может помочь, если при работе с текстом возникают затруднения, связанные с выявлением слов в переносном значении, а значит, и с трактовкой образов и важных для понимания произведения смыслов. Чем более экспрессивным (а значит, воздействующим, обращающим на себя внимание) является подобное нарушение, тем скорее данное выразительное средство актуализирует важные для понимания произведения смыслы.

2.4. Работа с контекстуальными синонимами и антонимами. Контекстуальные значения у синонимов и антонимов, возникающие в составе тропов, также всегда являются переносными. Выявление в тексте слов, развивающих новые, не свойственные им в системе языка связи, преследует цель выяснить характер трансформации семантической структуры слова в художественном тексте и тем самым более глубоко понять тот или иной образ.

Задание: определить, как трансформировали свое значение лексемы в синонимическом ряду или антонимической паре. «Пустой души пустых очарований Не победит ни зверь, ни человек. Несчастен, кто несет Коцитов дар стенаний На берегах земных веселых рек!» [42, с. 48]. Находим контекстуальные синонимы земныл, веселых. В синонимическом ряду (как и в антонимической паре) с контекстуальными синонимами (антонимами) трансформировать свое значение могут как все члены ряда (пары), так и отдельные. В последнем случае лексемы, сохранившие свое значение, «подтягивают» к 
Электронный научный журнал (Online). ISSN 2303-9922. http://www.vestospu.ru

себе остальные. Это и предопределяет направление трансформации. Рассматривая данный синонимический ряд, студенты приходят к заключению, что трансформирует свое значение слово земных, на что влияет семантика второго синонима - весельхх. За счет него в семантической структуре слова земных на первый план выходят семы, указывающие на радости жизни, которую применительно к поэтическому денотату реки мы можем трактовать как 'движение, скорость, сила, наполненность' и проч.

Или: «По-новому, спокойно и сурово, Живу на диком берегу. Ни праздного, ни ласкового слова Уже промолвить не могу» [4, т. 1, с. 115]. Студенты констатируют, что здесь мы имеем дело с контекстуальными антонимами. Этот случай немного сложнее, и мы предоставляем слово для сообщения студенту с небольшой справкой о лексеме праздный. Чтобы выявить характер трансформации слова (а значит, и связь с лексемой ласковый), необходимо обратиться к его происхождению. Старославянское слово праздньй с фонетической чертой неполногласием -ра- в русском языке имеет соответствие - слово порожний с полногласием. Следовательно, в семантической структуре слова праздный потенциально присутствует сема 'пустой'. Поэтому здесь данная лексема выражает значение «пустое, без теплоты, сопереживания, без ласки».

2.5. Работа с «оживлением» метафор и трансформацией фразеологизмов. Эти процессы также представляют собой виды трансформации значения, которая имеет внушительный экспрессивный потенциал и активно используется как в художественной литературе, так и в публицистическом стиле. Эти два явления (оживление метафоры и трансформация фразеологизмов) могут совпадать, если оживлению подвергается стертая метафора, утратившая свою двуплановость, образность и выразительность и являющаяся фразеологизмом. Но оживляться могут и просто метафоры, обладающие воспроизводимостью в текстах, ставшие штампами, но не имеющие статуса фразеологического оборота [20, с. 52]. Существует целый ряд приемов трансформации фразеологизмов и оживления метафор [14; 20; 21]. При этом семантика может как претерпевать значительные изменения, так и сохраняться. То же касается и формы: она может изменяться за счет распространения формулы, замены, эллипсиса, а может, наоборот, полностью сохраняться, но при этом совершенно меняется содержание.

Задание: выявить характер трансформации фразеологического оборота. Для этого нам нужно восстановить исходную формулу и сопоставить смысловое, эмоциональное и образное содержание исходного и трансформированного фразеологизма. «Но старость это Рим, который Взамен турусов и колес Не читки требует с актера, А полной гибели всерьез» [34, с. 83]. В трансформированном фразеологизме турусов и колес студенты узнают устойчивое выражение турусы на колесах. Сразу обращает на себя внимание изменение синтаксической конструкции. Вместо словосочетания, составленного на основе подчинительной связи управление, - словосочетание, составленное на основе сочинительной связи - однородные члены предложения. Фразеологизм турусы на колесах имеет значение 'пустая болтовня, чепуха, вздор'. В тексте Б. Пастернака речь идет о старости. Путем сравнения с поведением актера на сцене поэт говорит о том, как должен вести себя человек, дожив до преклонных лет. Актер не должен механически, не чувствуя ничего, читать текст, он должен проживать роль. Только тогда это будет настоящее серьезное искусство, воспитывающее в людях духовность. Поэтому на сцене нет места пустой болтовне. Не должно быть ей места и в старости, она должна быть мудрой. Человек в этом возрасте уже должен знать цену своего слова. В ходе беседы приходим к выводу, что собственно семантика фразеологизма не претерпела изменения. Однако претерпела изменение его синтаксическая конструкция и - что более важно - образная и идейная составляющие. 
Электронный научный журнал (Online). ISSN 2303-9922. http://www.vestospu.ru

Трансформированные фразеологизмы в художественном тексте своей «полуузнаваемостью» всегда притягивают дополнительное внимание читателя, вместе с тем обновляя, освежая стертую метафору, добавляя ей экспрессивный заряд. И тем самым углубляют центральный образ.

Данный вид работы представляет для студентов некоторую сложность, что в первую очередь связано с незнанием ими устойчивых выражений.

2.6. Работа со словами в новых - контекстуальных (трансформированных) значениях. Все предыдущие виды работ, по сути, являются подготовительными к этому виду, в котором надо прокомментировать, в чем именно состоит трансформация значения слова. Безусловно, этот вопрос связан со всеми рассмотренными ранее аспектами: и с видами переносных значений (метафора и метонимия - это разные типы трансформации), и с нарушением сочетаемости (она указывает на трансформацию), и с частными случаями трансформации значения слова (контекстуальными синонимами и антонимами, а также трансформацией фразеологизмов и оживлением метафор).

Задание: найти лексемы, которые претерпели трансформацию значения, определить характер трансформации. «Не знаю, решена ль Загадка зги загробной, Но жизнь как тишина Осенняя, - подробна» [34, с. 67]. Конечно, наше внимание сразу привлекает устаревшее слово зга. Направляем студентов к фразеологическому словарю и выясняем, что оно имеет значение 'дорога'. Данная лексема в силу своей архаичности имеет фразеологически связанное значение (о нем мы говорим на лексикологии, в курсе «Современного русского литературного языка») и в современном русском языке употребляется только в составе фразеологизма не видно ни зги, не сочетаясь с другими словами. Вследствие этого характер ассоциаций студентов может быть связан только с этим устойчивым выражением. В сочетании со словом загробная данная лексема трансформирует свое значение: 'дорога' $\rightarrow$ 'жизнь'. Жизнь в художественной литературе часто предстает в образе дороги, пути.

Далее анализируем слово подробна. Оно также обращает на себя наше внимание, потому что здесь мы видим явное нарушение сочетаемости слова (жизнь подробна). При помощи подбора синонимов студенты формулируют новую семантику данной лексемы: 'детальна'. Лексемы подробна и детальна близки по значению, но имеют разную сочетаемость. Мы приводим студентам мнение исследователей, которые отмечают, что для лирики Б. Пастернака характерна именно детальность изображения, причем детали в описании взаимозаменяемы, их выбор не важен [23, с. 329]. Следовательно, в данном произведении поэт выражает свое кредо.

Выявив слова, претерпевшие трансформацию, мы определяем вид тропов. У студентов этот этап в рассуждении не вызывает затруднений: и в случае со словом зга, и в случае со словом подробна мы имеем дело с метафорами, поскольку образ построен на сравнении (жизнь как зга, дорога; жизнь подробна, детальна, как долгий рассказ).

Далее выясняем, каков характер трансформации. В обоих случаях он заключатся в том, что одно слово выступает в значении другого, при этом подчеркивается общность некоторых признаков двух предметов, названных этими словами.

Студенты приходят к выводу, что эти две лексемы, трансформировавшие свое значение в составе метафоры, формируют центральный образ: мы не знаем, что нас ждет после смерти, но пока мы живы, значение имеет каждая деталь, каждая мелочь.

Или: «И безудержно - мой конь Любит бешеную скачку! — Я метала бы в огонь Прошлое - за пачкой пачку» [43, с. 114]. В данном случае студенты достаточно легко находят слово, которое трансформировало свое значение. Это лексема прошлое, выступающая в значении «письма из прошлого (о прошлом)». Уже по формулировке значений 
Электронный научный журнал (Online). ISSN 2303-9922. http://www.vestospu.ru

они видят, что трансформация практически не касается значения слов, участвующих в создании тропа, а затрагивает их синтаксические связи (сокращает конструкцию), что характерно для такого вида переносных значений, как метонимия.

Заключение. Если способность создавать текст является показателем грамотности любого носителя языка, то способность анализировать текст является показателем сформированности необходимых компетенций студента-филолога. И этот уровень должен быть достаточно высоким, так как речь идет о будущих учителях, которым предстоит учить этому анализу школьников. Опираясь на художественные тексты, которые изучаются в школе, они должны будут и воспитывать учащихся, правильно расставляя ценностные приоритеты, и учить их видеть красоту и действенность русского слова.

Как отмечают исследователи, «современная школьная практика обучения языку активно перестраивается на основе текстоориентированного подхода, способствующего развитию умений понимания и порождения связной речи» [16, с. 77]. Подобная перестройка требует от студентов-филологов — будущих учителей - систематизации всех полученных в процессе обучения знаний и умений, а также сформированности всех необходимых компетенций. Оценить себя в этом отношении и тем самым осуществить рефлексию и призваны занятия по дисциплине «Филологический анализ текста».

Итак, нами рассмотрены наиболее перспективные приемы работы со средствами лексического уровня языка художественного текста, которые мы объединили в две группы: 1) наблюдение над выбором слов; 2) наблюдение над трансформацией значения слова в художественном тексте. Работа с различными аспектами анализа текста по этим двум направлениям поможет выявить и проанализировать все важные составляющие художественного текста, понимание которых будет способствовать объективности и адекватности филологического анализа.

Отметим еще одну очень важную функцию дисциплины «Филологический анализ текста» в целом и работы со средствами лексического уровня в частности. Анализ смысловой и эмоциональной сторон художественного текста во всей полноте (на материале высокодуховной русской литературы) активно работает и на формирование «правильных» ценностных жизненных ориентиров, что важно и для студентов, и для школьников.

\section{Список использованной литературы}

1. Андреева И. Ю. Анализ языковых средств произведения как способ постижения авторского замысла (Из опыта учителя) // Русский язык в школе. 2016. № 4. С. 12-16.

2. Аристова М. А., Критарова Ж. Н. Лексическая работа в процессе анализа художественных текстов (На материале современного учебника для полиэтнической школы) // Русский язык в школе. 2018. № 9. C. $16-21$.

3. Арнольд И. В. Семантика. Стилистика. Интертекстуальность. СПб. : Изд-во Санкт-Петерб. ун-та, 1999. $443 \mathrm{c}$.

4. Ахматова А. Сочинения : в 2 т. М., 1990.

5. Башкова Л. Р. Ключевые элементы в поэтическом тексте // Русский язык в школе. 2008. № 2. C. $49-52$.

6. Белова А. П. Речетворческий анализ поэтических текстов Варлама Шаламова на уроках русского языка // Русский язык в школе. 2018. № 7. С. 25-30.

7. Блохин А. В. Комплексный лингвистический анализ текста как задание для развернутого письменного ответа на ЕГЭ по русскому языку (профильный уровень) // Русский язык в школе. 2015 . № 5. C. $10-13$.

8. Болотнова Н. С. Лексическая структура поэтического текста как ключ к постижению его ценностных смыслов // Русский язык в школе. 2019. № 1. С. 20-25.

9. Болотнова Н. С. Методика поуровневого лингвосмыслового анализа поэтического текста и ее использование в школе // Русский язык в школе. 2015. № 6. С. 16-22.

10. Болотнова Н. С. Филологический анализ текста : учеб. пособие. 4-е изд. М. : Флинта : Наука, 2009. $520 \mathrm{c}$. 


\section{Электронный научный журнал (Online). ISSN 2303-9922. http://www.vestospu.ru}

11. Бродский И. Сочинения : в 4 т. М., 1994.

12. Бунин И. А. Стихотворения. Рассказы. М., 1986.

13. Гаспаров М. Л. Избранные труды. Т. 2: О стихах. М. : Языки русской культуры, 1997. 501 с.

14. Гольцова Н. Г. Окказиональность слова и окказиональность фразеологизма // Русский язык в школе. 1993. № 3. С. $81-86$.

15. Грязнова А. Т. Лингвопоэтический анализ стихотворения А. А. Бестужева-Марлинского «Осень» // Русский язык в школе. 2017. № 6. С. 57-62.

16. Дейкина А. Д., Левушкина О. Н. Характеристика текста как вида учебной деятельности в современном школьном обучении русскому языку // Мир русского слова. 2011. № 2. С. 77 -84.

17. Иванов Г. В. Стихотворения. М., 2006.

18. Иванова О. Е. Словарь языка поэзии (образный арсенал русской лирики конца XVIII - начала ХХ века). М. : АСТ, 2004. 668 с.

19. Ипполитова Н. А. Что нужно знать учителю о тексте как феномене культуры // Русский язык в школе. 2016. № 4. С. 3-7.

20. Кузнецова Н. Н. Оживление метафоры как способ создания экспрессивности // Русская словесность. 2009. № 4. С. 52-56.

21. Кузнецова Н. Н. Трансформация фразеологических единиц в поэтическом тексте как средство создания экспрессивности // Проблемы истории, филологии, культуры. М. ; Магнитогорск ; Новосибирск, 2009. Вып. 3. С. 283-292.

22. Кузнецова Н. Н. О подтексте при использовании ключевых слов в художественном тексте // Языковая норма и речевая практика в Оренбургском регионе : материалы науч. конф. : в 2 ч. Оренбург, 2016. Ч. 1. С. $86-89$.

23. Кузнецова Н. Н. Средства создания экспрессивности в русской поэзии XX века : дис. ... д-ра филол. наук. М., 2011. 594 с.

24. Левушкина О. Н. Зимнее солнце цвета ягоды морошки (Урок характеристики текста в VI классе) // Русский язык в школе. 2015. № 11. С. 20-23.

25. Лотман Ю. М. О поэтах и поэзии. Анализ поэтического текста. СПб. : Искусство, 2001. 846 с.

26. Мандельштам О. Э. Избранное. Смоленск, 2002.

27. Набоков В. Н. Стихотворения и поэмы. М., 1991.

28. Николина Н. А. Филологический анализ текста : учеб. пособие для студ. высш. пед. учеб. заведений. М. : Издат. центр «Академия», 2003. 256 с.

29. Новиков Л. А. Художественный текст и его анализ. 3-е изд. М. : URSS ЛКИ, 2007. 300 с.

30. Очерки истории языка русской поэзии XX в. Образные средства поэтического языка и их трансформация / под ред. В. П. Григорьева. М. : Наука, 1995. 263 с.

31. Очерки истории языка русской поэзии XX в. Опыты описания идиостилей / под ред. В. П. Григорьева. М. : Наследие, 1995. 558 с.

32. Очерки истории языка русской поэзии XX в. Поэтический язык и идиостиль. Общие вопросы. Звуковая организация текста / под ред. В. П. Григорьева. М. : Наука, 1990. 304 с.

33. Панова Е. А. Лингвопоэтический анализ стихотворения А. Дельвига «Пусть нам даны не навсегда...» // Русский язык в школе. 2018. № 7. С. 67-71.

34. Пастернак Б. Стихотворения и поэмы. М., 1990.

35. Пахнова Т. М. «Единственное мне принадлежащее сокровище - это русская речь» (Тексты Беллы Ахмадулиной на уроках русского языка) // Русский язык в школе. 2017. № 4. С. 25-29.

36. Пискунова С. В. Тайны поэтической речи (грамматические формы и семантика текста). Тамбов : ТГУ, 2002. 408 с.

37. Словарь языка русской поэзии ХХ века. Т. 3 : 3 - Круг / сост. В. П. Григорьев, Л. Л. Шестакова, В. В. Бакеркина, А. В. Гик, Л. И. Колодяжная, Т. Е. Реутт, Н. А. Фатеева. М. : Языки славянской культуры, 2008. XIV, 771, [2] c.

38. Слово. Образ. Смысл: филологический анализ литературного произведения. $10-11$ кл. : учеб. пособие / под ред. В. Ф. Чертова. М. : Дрофа, 2005.

39. Сулименко Н. Е. Текст и аспекты его лексического анализа : учеб. пособие. М. : Флинта : Наука, 2009. $396 \mathrm{c}$.

40. Токарева И. Ю. Применение концептуального анализа ключевых слов культуры при подготовке к итоговому сочинению // Русский язык в школе. 2017. № 11. С. 3-5.

41. Фоменко И. В. Практическая поэтика. М. : Академия, 2006. 192 с.

42. Ходасевич В. Ф. Собрание стихов. М., 1992.

43. Цветаева М. Через сотни разъединяющих лет... Свердловск, 1989.

Поступила в редакцию 12.02.2019 


\section{Электронный научный журнал (Online). ISSN 2303-9922. http://www.vestospu.ru}

Кузнецова Наталья Николаевна, доктор филологических наук, доцент

Оренбургский государственный педагогический университет

Российская Федерация, 460014, г. Оренбург, ул. Советская, 19

E-mail: Natlog65@mail.ru

UDC 372.881.161.1

\section{N. N. Kuznetsova}

\section{Methodical techniques of vocabulary training at the lessons in philological analysis of the text in a pedagogical university}

The article is devoted to the topical methodological problem — the development of techniques to work with a text in the classroom in "Philological analysis of the text" and specific methods of lexical analysis. The author has developed and tested a number of techniques for working with the lexical means of a literary text, which, for all their diversity, can be combined into three main groups: observation of the choice of words, observation of the transformation of the meaning of a word in the literary text, and observation of the ways to express the author's individuality. In the course of philological analysis, they occupy a central place, since it is these tools that convey the main content of the work and indicate the author's value reference points. The article presents the techniques of the first two groups.

Key words: literary text, philological analysis of the text, students of a pedagogical university, methods of working with lexical means, word choice, transformation of a word meaning, incompatibility.

Kuznetsova Natalia Nikolaevna, Doctor of Philological Sciences, Associate Professor

Orenburg State Pedagogical University

Russian Federation, 460014, Orenburg, ul. Sovetskaya, 19

E-mail: Natlog65@mail.ru

\section{References}

1. Andreeva I. Yu. Analiz yazykovykh sredstv proizvedeniya kak sposob postizheniya avtorskogo zamysla (Iz opyta uchitelya) [Analysis of the linguistic means of the literary work as a way of comprehending the author's intent]. Russkii yazyk v shkole - Russian language at school, 2016, no. 4, pp. 12-16. (In Russian)

2. Aristova M. A., Kritarova Zh. N. Leksicheskaya rabota v protsesse analiza khudozhestvennykh tekstov (Na materiale sovremennogo uchebnika dlya polietnicheskoi shkoly) [Vocabulary work in the process of analyzing literary texts (on the material of the modern textbook for a multiethnic school)]. Russkii yazyk v shkole - Russian language at school, 2018, no. 9, pp. 16-21. (In Russian)

3. Arnol'd I. V. Semantika. Stilistika. Intertekstual'nost' [Semantics. The style. Intertextuality]. St. Petersburg, Sankt-Peterb. un-t Publ., 1999. 443 p. (In Russian)

4. Akhmatova A. Sochineniya: v 2 t. [Works. In 2 vol.]. Moscow, 1990. (In Russian)

5. Bashkova L. R. Klyuchevye elementy v poeticheskom tekste [Key elements in a poetic text]. Russkii yazyk $v$ shkole - Russian language at school, 2008, no. 2, pp. 49-52. (In Russian)

6. Belova A. P. Rechetvorcheskii analiz poeticheskikh tekstov Varlama Shalamova na urokakh russkogo yazyka [The speechmaking analysis of the poetic texts by V. Shalamov at Russian language lessons]. Russkii yazyk v shkole - Russian language at school, 2018, no. 7, pp. 25-30. (In Russian)

7. Blokhin A. V. Kompleksnyi lingvisticheskii analiz teksta kak zadanie dlya razvernutogo pis'mennogo otveta na EGE po russkomu yazyku (profil'nyi uroven') [Complex linguistic analysis of the text as a task for a comprehensive written response to the exam in the Russian language (profile level)]. Russkii yazyk v shkole Russian language at school, 2015, no. 5, pp. 10-13. (In Russian)

8. Bolotnova N. S. Leksicheskaya struktura poeticheskogo teksta kak klyuch k postizheniyu ego tsennostnykh smyslov [Lexical structure of the poetic text as a key to the comprehension of its inherent values]. Russkii yazyk $v$ shkole - Russian language at school, 2019, no. 1, pp. 20-25. (In Russian)

9. Bolotnova N. S. Metodika pourovnevogo lingvosmyslovogo analiza poeticheskogo teksta i ee ispol'zovanie $\mathrm{v}$ shkole [The methodology of the level-based linguistic-semantic analysis of the poetic text and its use in school]. Russkii yazyk v shkole - Russian language at school, 2015. № 6. C. 16-22. (In Russian) 


\section{Электронный научный журнал (Online). ISSN 2303-9922. http://www.vestospu.ru}

10. Bolotnova N. S. Filologicheskii analiz teksta. 4-e izd. [Philological analysis of the text. $4^{\text {th }}$ ed.]. Moscow, Flinta, Nauka Publ., 2009. 520 p. (In Russian)

11. Brodskii I. Sochineniya: v 4 t. [Works. In 4 vol.]. Moscow, 1994. (In Russian)

12. Bunin I. A. Stikhotvoreniya. Rasskazy [Poesy. The stories]. Moscow, 1986. (In Russian)

13. Gasparov M. L. Izbrannye trudy. T. 2: O stikhakh [Selected Works. Vol. 2: About Poesy]. Moscow, Yazyki russkoi kul'tury Publ., 1997. 501 p. (In Russian)

14. Gol'tsova N. G. Okkazional'nost' slova i okkazional'nost' frazeologizma [Occasionality of a word and occasionality of phraseologism]. Russkii yazyk v shkole - Russian language at school, 1993, no. 3, pp. 81-86. (In Russian)

15. Gryaznova A. T. Lingvopoeticheskii analiz stikhotvoreniya A. A. Bestuzheva-Marlinskogo "Osen'» [Linguistic-poetic analysis of the poem by A. A. Bestuzhev-Marlinsky "Autumn"]. Russkii yazyk v shkole Russian language at school, 2017, no. 6, pp. 57-62. (In Russian)

16. Deikina A. D., Levushkina O. N. Kharakteristika teksta kak vida uchebnoi deyatel'nosti v sovremennom shkol'nom obuchenii russkomu yazyku [Characterization of the text as a type of educational activity in modern school teaching of the Russian language]. Mir russkogo slova - The World of Russian Word, 2011, no. 2, pp. 77-84. (In Russian)

17. Ivanov G. V. Stikhotvoreniya [Poesy]. Moscow, 2006. (In Russian)

18. Ivanova O. E. Slovar' yazyka poezii (obraznyi arsenal russkoi liriki kontsa XVIII - nachala XX veka) [Dictionary of the language of poetry (figurative arsenal of Russian lyrics of the late $18^{\text {th }}-$ early $20^{\text {th }}$ centuries)]. Moscow, AST Publ., 2004. 668 p. (In Russian)

19. Ippolitova N. A. Chto nuzhno znat' uchitelyu o tekste kak fenomene kul'tury [What a teacher needs to know about a text as a cultural phenomenon]. Russkii yazyk v shkole - Russian language at school, 2016, no. 4, pp. 3-7. (In Russian)

20. Kuznetsova N. N. Ozhivlenie metafory kak sposob sozdaniya ekspressivnosti [Revitalizing metaphors as a way to create expressivity]. Russkaya slovesnost', 2009, no. 4, pp. 52-56. (In Russian)

21. Kuznetsova N. N. Transformatsiya frazeologicheskikh edinits v poeticheskom tekste kak sredstvo sozdaniya ekspressivnosti [Transformation of phraseological units in a poetic text as a means of creating expressivity]. Problemy istorii, filologii, kul'tury [Problems of History, Philology, Culture]. Moscow, Magnitogorsk, Novosibirsk, 2009. Is. 3, pp. 283-292. (In Russian)

22. Kuznetsova N. N. O podtekste pri ispol'zovanii klyuchevykh slov v khudozhestvennom tekste [On the subtext when using keywords in a literary text]. Yazykovaya norma i rechevaya praktika v Orenburgskom regione: materialy nauch. konf.: $v 2 \mathrm{ch}$. [Language norm and speech practice in the Orenburg region. Proceed. of sci. conf. In 2 parts]. Orenburg, 2016, part 1, pp. 86-89. (In Russian)

23. Kuznetsova N. N. Sredstva sozdaniya ekspressivnosti v russkoi poezii XX veka: dis. ... d-ra filol. nauk [Means of creating expressivity in Russian poetry of the XX century. Dr. Dis.]. Moscow, 2011. 594 p. (In Russian)

24. Levushkina O. N. Zimnee solntse tsveta yagody moroshki (Urok kharakteristiki teksta v VI klasse) [Winter sun of cloudberry color (Lesson on text characteristics in $\mathrm{VI}^{\text {th }}$ form)]. Russkii yazyk v shkole - Russian language at school, 2015, no. 11, pp. 20-23. (In Russian)

25. Lotman Yu. M. O poetakh i poezii. Analiz poeticheskogo teksta [About poets and poetry. Poetic text analysis]. St. Petersburg, Iskusstvo Publ., 2001. 846 p. (In Russian)

26. Mandel'shtam O. E. Izbrannoe [Selected writings]. Smolensk, 2002. (In Russian)

27. Nabokov V. N. Stikhotvoreniya i poemy [Poesy and poems]. Moscow, 1991. (In Russian)

28. Nikolina N. A. Filologicheskii analiz teksta [Philological analysis of the text]. Moscow, Akademiya Publ., 2003. 256 p. (In Russian)

29. Novikov L. A. Khudozhestvennyi tekst i ego analiz. 3-e izd. [Literary text and its analysis. $3^{\text {rd }}$ ed.]. Moscow, URSS LKI Publ., 2007. 300 p. (In Russian)

30. Ocherki istorii yazyka russkoi poezii XX v. Obraznye sredstva poeticheskogo yazyka i ikh transformatsiya [Essays on the history of the language of Russian poetry of the twentieth century. Imaginative means of poetic language and their transformation]. Moscow, Nauka Publ., 1995. 263 p. (In Russian)

31. Ocherki istorii yazyka russkoi poezii XXv. Opyty opisaniya idiostilei [Essays on the history of the language of Russian poetry of the twentieth century. The experiences of describing the individual author styles]. Moscow, Nasledie Publ., 1995. 558 p. (In Russian)

32. Ocherki istorii yazyka russkoi poezii XX v. Poeticheskii yazyk i idiostil'. Obshchie voprosy. Zvukovaya organizatsiya teksta [Essays on the history of the language of Russian poetry of the twentieth century. Poetic language and individual author style. General issues. Sound organization of the text]. Moscow, Nauka Publ., 1990. 304 p. (In Russian)

33. Panova E. A. Lingvopoeticheskii analiz stikhotvoreniya A. Del'viga "Pust' nam dany ne navsegda..." [Linguopoetic Analysis of A. Del'vig's Poem "Pust' Nam Dany ne Navsegda..."]. Russkii yazyk v shkole — Russian language at school, 2018, no. 7, pp. 67-71. (In Russian) 


\section{Электронный научный журнал (Online). ISSN 2303-9922. http://www.vestospu.ru}

34. Pasternak B. Stikhotvoreniya i poemy [Poesy and poems]. Moscow, 1990. (In Russian)

35. Pakhnova T. M. "Edinstvennoe mne prinadlezhashchee sokrovishche — eto russkaya rech"” (Teksty Belly Akhmadulinoi na urokakh russkogo yazyka) ["The only treasure I own is the Russian language" (Texts by Bella Akhmadulina at the lessons of the Russian language)]. Russkii yazyk v shkole - Russian language at school, 2017, no. 4, pp. 25-29. (In Russian)

36. Piskunova S. V. Tainy poeticheskoi rechi (grammaticheskie formy i semantika teksta) [Secrets of poetic speech (grammar forms and semantics of the text)]. Tambov, TGU Publ., 2002. 408 p. (In Russian)

37. Grigor'ev V. P., Shestakova L. L., Bakerkina V. V., Gik A. V., Kolodyazhnaya L. I., Reutt T. E., Fateeva N. A. (comp.) Slovar'yazyka russkoi poezii XX veka. T. 3. Z - Krug [Dictionary of the language of Russian poetry of the XX century. Vol. 3. Z — Circle]. Moscow, Yazyki slavyanskoi kul'tury Publ., 2008. XIV, 771, [2] p. (In Russian)

38. Slovo. Obraz. Smysl: filologicheskii analiz literaturnogo proizvedeniya. 10-11 kl. [Word. Form. Sense: philological analysis of a literary work. Grades 10-11]. Moscow, Drofa Publ., 2005. (In Russian)

39. Sulimenko N. E. Tekst $i$ aspekty ego leksicheskogo analiza [Text and aspects of its lexical analysis]. Moscow, Flinta, Nauka Publ., 2009. 396 p. (In Russian)

40. Tokareva I. Yu. Primenenie kontseptual'nogo analiza klyuchevykh slov kul'tury pri podgotovke k itogovomu sochineniyu [Application of the conceptual analysis of cultural keywords in preparation for the final essay]. Russkii yazyk v shkole - Russian language at school, 2017, no. 11, pp. 3-5. (In Russian)

41. Fomenko I. V. Prakticheskaya poetika [Practical poetics]. Moscow, Akademiya Publ., 2006. 192 p. (In Russian)

42. Khodasevich V. F. Sobranie stikhov [Collection of poems]. Moscow, 1992. (In Russian)

43. Tsvetaeva M. Cherez sotni raz"edinyayushchikh let... [After hundreds of disconnecting years...]. Sverdlovsk, 1989. (In Russian) 